\title{
Nowoczesne fontanny w miejskiej przestrzeni publicznej
}

\section{Modern fountains in an urban public space}

\section{Streszczenie}

Różnorodne sztuczne zbiorniki wodne w postaci fontann, kaskad, oczek wodnych itd. są powszechnym elementem w prze strzeni publcznej miasta. Takie elementy wodne umieszczano $w$ przestrzeni miejskiej od czasow antycznych - służyły potrzebom utyltarnym oraz upiększaly przestrzeń miejską lub ogrodowa. Wspólczesnie w procesie ksztaltowania przestrzen nologiczne umożliwiajace sterowanie strumieniami wodnymi oraz kreowanie różnorodnych efektów świetlnych. Miejikie fontanny i kaskady projektuje sie również z uwzglednieniem zasad zrównoważonego projektowania - są zailan wodam opadowymi a ich rozmieszczenie w przestrzeniach publicznych pozytywnie wptywa na miejski mikroklimat. Takie całościowe podejście do projektowania miejskich fontann sprawia że coraz cześciej i chetniej widzimy je w najblizszym otoczeni a bardzo często stają się one wizytówkami i atrakcjami turystycznymi miast.

\section{Abstract}

A spaces of cities. Such water-based elements have been placed in urban spaces since ancient times - they served utilitarian needs and beautified urban or garden spaces. Currently, in the process of the shaping of city spaces, fountains and various types of small water bodies also make an appearance. Today, they utilise technological solutions that make it possible to control water streams and create diverse lighting effects. Urban fountains and cascades are also being designed while taking into account principles of sustainable design - they use rainwater and their placement in public spaces positively affects the Uhan micfoclimate. Such a holistic approach to the design of urban fountains leads to the fact that we see them more often attractions of cities.



\section{Wprowadzeni}

W czasach historycznych sztuczne założenia wodne w przetrzeni miejskiej instalowano przede wszystkim z pobudek utylitarnych. $Z$ braku powszechnego dostępu do wody zbiorniki dostarczały niezbędnej wody do picia i do potrzeb sanitarno-higienicznych. Z czasem w dużych ośrodkach miejskich takich jak starożytny Rzym powstały bogato zdobione załoenia wodne - nimfea, które były umieszczane w miejscach zakończenia trasy akweduktów dostarczających świeżą wode do miasta. Nimfea służyły mieszkańcom miast do czerpania wody, ale również były umieszczane $w$ strategicznych punktach miasta - przy ważnych drogach prowadzących do centrum Rzymu. Te, często wielokondygnacyjne, fontanny symbolizowały potęgę starożytnego imperium i miały za zadanie wzbudzać podziw u przybywających do miasta podróżnych. $W$ czasach antycznych budowano fontanny i zbiorniki wodne nie tylko w przestrzeni miejskiej - powstawały one również $w$ rozległych założeniach ogrodowych. Tutaj woda nie miała przede wszystkim przeznaczenia użytkowego, ogrodowe założenia wodne tworzono w celu podkreślenia piękna małej

\section{Introduction}

In historical times, artificial water layouts were established in urban spaces chiefly because of utilitorian reasons. Due to the lack of common access for drinking, in addition to sanitary, as well as hygienic purposes. Over time, richly decorated water layouts were built in urban centres such as ancien Rome - they were called nymphaeum, and would provided water to the city. Nymphaea were the by residents to obtain water, but were also placed in strategic points throughout the city - near imortant roads leading to the centre of Rome. These - often multi-level-fountains symbolised the might of the ancient empire and were to elicit admiration travellers coming to the city.

In ancient times, fountains and water reservoirs were built not only in urban spaces - they were also maver lavouts were established in order to highlight the architektury, sztuki oraz otaczającej je natury. Jednym z najtożeniami wodnymi w starożytności były ogrody przy Willi Hadriana w Tivoli. Na rozległym obszarze powstały różnorodne baseny i kaskady wodne otoczone antycznymi rzeźbami i służące rekreacji lub rozrywce (spektakle teatralne rozgrywano w Natatorium -budowli położonej na wyspie otoczone kanałem wodnym)'.

Od czasów starożytnego Rzymu formy wodne towarzyszyły zarówno założeniom ogrodym, ale również pojawsty syę w przestrzeni miejkich pláów i lic. Ioh ska pojawiały sié nity sie od siebie ze wzgledów funkcjonalnych. Ogrodowe wiy sie od siebie ze wz fontann i kaskady waz z rozwojem tech - rozli we okresie reje przestzen

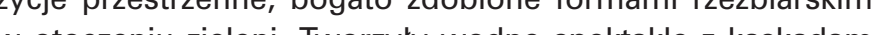

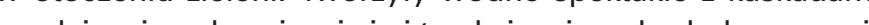
spadającej, rozlowającej się i tryskającej wody. Jednym z najznamienitszych przykladów takiego zalożenia jest teatr wodny w willi d'Este połozonej w Tivoli niedaleko Rzymu. Styl i charakter tego zalożenia palacowo-grodowego inspirowany by (jak cała epoka renesansu) antycznymi wzorcami dotyczacymi architektury i sztuki. Wodne elementy pojawiające się $w$ renesansowych ogrodach, tak jak $w$ antyku, miały przede wszystkim znaczenie estetyczne, słuzyły rozrywce, relaksow podkreslały piękno przyrody i naturalnego krajobrazu. Teat wodny w willi d'Este rozłożony jest na stoku, z którego woda opada w kilkudziesięciu różnorodnych wodospadach i kaskadach - w ten sposób wykorzystano wszystkie efekty estetyczne jakie oferuje woda: światło i kolor, dźwięk, ruch, zmiana faktury i transparentności.

Miejskie fontanny w różnych epokach historycznych odbiegafy formą i skalą od wodnych założeń ogrodowych. Powstawały przede wszystkim w miejskiej przestrzeni publicznej, gdzie wcześniej funkcjonowała studnia lub inne ujęcie wody. Z czasem fontanny ozdabiane były rzeźbiarskimi formami, a ich charakter utrzymywany w stylu epoki, w której powstały. Wiele z historycznych miejskich fontann dziś stało sie cennym zabytkami w przestrzeni historycznych placów i ulic a nawe jednymi z najważniejszych atrakcji turystycznych. Wśród wie je znanych realizacj wato tu wa turysté min. o tak zn wie jak renesan fontanna zzéza Neptun przy Pabzzo Vechio we Florencil czy najbardzie zeptu brzy Palazzo Vec-

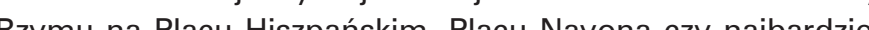
Rzymu a Plocu czy najbardzej zna znana fontanna di Trevi, Ktora jest unikalnym połączeniem wody i architektury wabudowie miejskiej.

Do czasow rewolucji przenyslowej formy wodne w przestrzeni publicznej stuzyly przede wszystkim podkreśleniu rangi i prestiżu założeń pałacowo - ogrodowych należących do władców i arystokracji. Ich walory estetyczne: gra świateł $i$ kolorów, towarzyszące bogate rzezbienia itd. mogły podziwiać uprzywilejowane grupy osób. Dopiero w XIX wieku zaczęly powstawac pierwsze ogolnodostępne przestrzenie miejskie o charakterze rekreacyjnym - parki i skwery miejskie. Razem z zielenią zakładano $w$ nich założenia wodne - stawy, baseny lub inne zbiorniki wodne oraz towarzyszące im fontanny, w których płynąca i tryskająca woda miała zapewniac mieszkańcom miast epoki przemysłowej kontakt z natura. surrounded it. One of the greatest examples of gardens composed with water layouts in antiquity poets and warer cascan's Villa in Tivoli. Various pools and water cascades surrounded by ancien for recreation or entertainment /theatrical shows were played out at the Natatorium - a structure built on an island surrounded by a water canal) '.

Since the time of ancient Rome, water forms have accompanied both garden layouts, as well as ap peared in the spaces of city squares and streets. for functional reasons. Garden fountin each other cades, along with the development of technology during the Renaissance period, evolved into socalled "water theatres" - vast spatial compositions, richly decorated with sculptural forms, surrounded by greenery. They formed water spectacles with One of the most illustrious exand sprinkling water. out is the water theatre at the Villa d'Este located in Tivoli, near Rome. The style and character of this palace and garden layout had been inspired (just like the entire period of the Renaissance) by ancient patterns in architecture and art. The water elements that appeared in Renaissance gardens, just like in he ancient period, were mostly of aesthetic signifation, as well as highlighting the beauty of nature and the natural landscape. The water theatre in the Villa d'Este is laid out on a hillside, from which water falls in tens of various different waterfalls and cascades - thus utilising all the aesthetic effects of fered by water. light and colour, sound, movemen thanges in texture and ransparency,

政 periods. They were built mainly in urban public spaces, where previously a well or a different water source had functioned. Over time, fountain were decorated with sculptural forms, and their character was kept in the style of the period durfountains have currently become valued historical monuments in the spaces of historical square and streets, and even some of the most important tourist attractions. Among many famous works, would be fitting to mention those that are as famous as the Renaissance fountain with the sculpor the most famous Baroque fountains of Rome on the Spanish Square, the Piazza Navona or the most well-known - the di Trevi fountain, which is
a unique combination of water and architecture within an urban environment.

Up to the period of the industrial revolution, wator forms featured in public spaces served chiefly garden layouts belonging to rulers and the aristocracy. Their aesthetic qualities: the play of light and colour, the accompanying rich sculptures, etc. could only be marvelled at by privileged groups of people. It was only in the XIX century that the firs widely accossible unban spaces of a recreation character started to be built - such as parks and uralong with greenery - ponds, pools or other wate reservoirs, along with accompanying fountains, in 


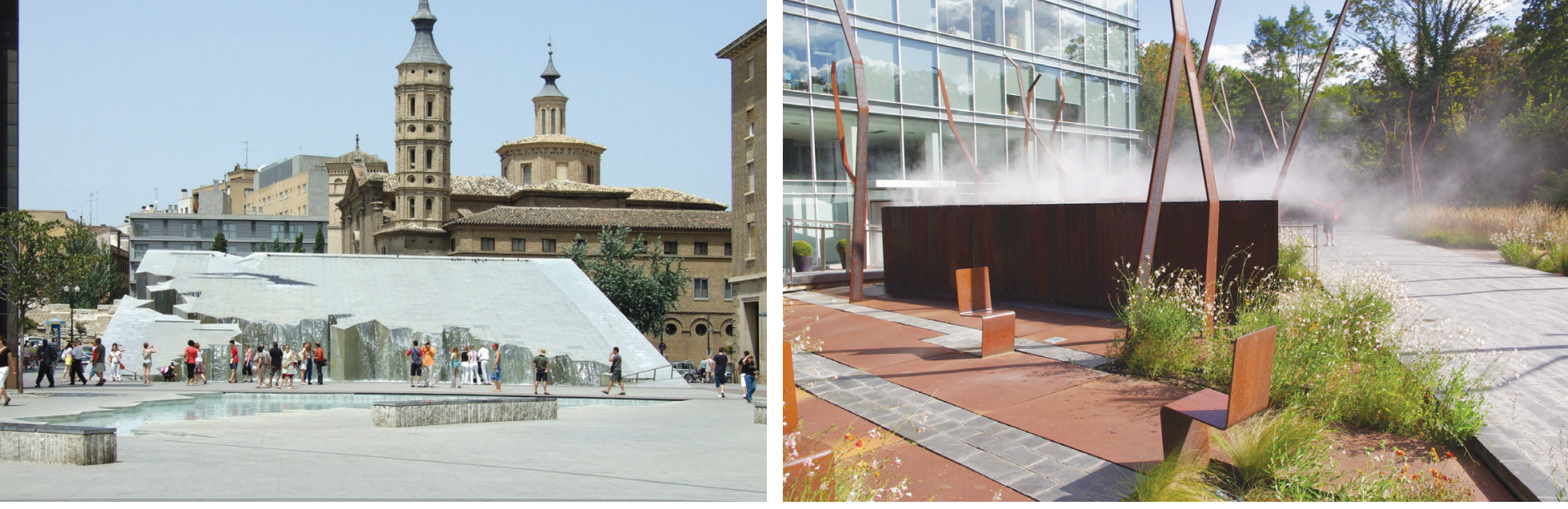

II. 1. Plaza del Pilar $w$ Saragossie - przykład fontanny w historycznej przestrzeni placu miejskiego. Autor: E.Kusińska / Plaza del Pilar in Sara-
gossia - an example of a fountain in the historical space of an urban square. Author: E. Kusińska

II. 2. Floorworks - ogród miejski z mgłą wodną w Genewie. Autor: E. Kusińska / Floorworks - an urban garden with a water mist in Geneva.
Author: E. Kusińska

W XIX w. bardzo intensywnie zaczęły się rozwijać miejscowości uzdrowiskowe - wiązało się to $z$ upowszechnieniem zdrowego stylu życia, ale również z rewolucją przemysłową i rozwojem kolei. Dzięki temu szersze grupy społeczne mogły korzystać z leczniczych właściwości wód mineralnych czy termalnych. W miejscowościach uzdrowiskowych powstawały przestrzenie publiczne, w których znaczącą rolę odgrywały elementy wodne oraz budynki związane $z$ wodą: łaźnie, pijalnie, termy itd. Funkcje przestrzeni publicznych uzdrowisk były związane z formą spędzania czasu wolnego przez kuracjuszy. Dlatego dla ich wygody powstawały parki zdrojowe, deptaki, promenady, ogrody i place - a w wielu miejscach umieszcza-
no fontanny (czesto z pitna woda), które podkreślały uzdrowiskowy charakter miejsca i dodawały wrażeń estetycznych użytkownikom przestrzeni publicznych

Warto tu wspomnieć o polskich uzdrowiskach, w których powstało wiele pieknych i charakterystycznych form wodnych jak np fontanny w Dusznikech Zdroju, Krynicy, Szczawnicy i innych miastach. Wiekszość z nich istnieje do dzisiaj w miejkich przestzentach publicznych i staly sie a dakcja-

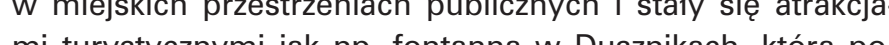
mi turysty 1205 r. Juz wp wstala w

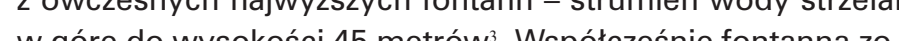
w górę do wysokosci 45 metrów. Wspólcześnie fontanna została odrestaurowana i $w$ czasie letnim podświetlona i grajaca fontanna prezentuje spektakle wodno-swietho-muzczne wykorzystujące ruchome strumienie wody.

2. Miejskie formy wodne $w$ projektowaniu zrównoważonym W XX wieku zaczęto dostrzegać znaczenie miejskich form wodnych nie tylko jako elementów estetycznych w przestrzeni publicznej. Już w Karcie Ateńskiej pojawiały się postulaty o potrzebie kontaktu człowieka "miejskiego" z przyrodą, której deficyt obserwowano w miastach pierwszej połowy ubiegłego stulecia. Z czasem, głównie dzięki działaniom w ramach ONZ rozwinęły się badania nad jakością środowiska, aby przeciwdziałać jego nadmiernej degradacji postępującej wskutek procesów urbanizacyjnych. Pod koniec lat 80 . XX wieku4 sformułowanio założenia idei zrównoważonego rozwoju jako takiego rozwoju społeczno-gospodarczego krajów, Zdroj, Krynica, Szczawnica and other towns, were tractions, like the fountain in Duszniki, which was tains - the stream of water would shoot up to light and music-based spectacles, using movin który troszczy się o zasoby naturalne i przyrodnicze mając na uwadze obecna populacje i przyszle pokolenia. Obecnie polityka zrównoważonego rozwoju, a w zakresie budownictwa oraz urbanistyki - zrównoważonego projektowania, jest podstawą działań i przepisów prawnych bardzo wielu krajów. Podnoszenie jakości przestrzeni miejskiej w myśl zasad zrównoważonego rozwoju polega m.in. na zapewnieniu mieszkańcom miast kontaktu z naturą i przyroda. Dziẹki różnorodnym badaniom naukowym dziś wiadomo, że elementy natury takie a zién otoczeniu dl zachowania zdrowia psychofizycznego wazine sa opracowania noukow ploczace pozytywego dzin wać wiele negatywy zjawisk sodowiskowch zojiwelowac wiele nega cych sie wskutek nadmienego zabudowy wa prestzen miejskiej. Tradycyjne gospodarowanie wodą w mieście kierunkowane na jak najszybsze i najefektywniejsze odprowadzenie wód opadowych z terenów zabudowanych prowadz do nadmiern go wysuszania powietrza oraz Wzrostu temperatury. Brak wody prowadzi rownież do zaniku i degradacj miejskich ekosystemów przyrodniczych - zmniejszania się ilości terenów zielonych oraz niższej bioróżnorodności. Podwyższona temperatura w mieście (zwłaszcza utrzymująca się w dłuższym okresie) przede wszystkim negatywnie wpływa na samopoczucie czlowieka powodując zmęczenie i osłabienie. $W$ przypadku osob szczegolnie wrazliwych, takich jak osoby starsze, male dzieci, osoby przewlekle chore - suche gorące powietrze może doprowadzić do nasilenia się róż norodnych objawów chorobowych takich jak: astma, alergia choroby układu krazżenia, czy układu oddechowego. ${ }^{5}$ Warto wspomnieć, że suche i gorące powietrze wykazuje znacznie podwyższoną ilość pyłów i zanieczyszczeń i szybciej roznosza się w nim pyłki drzew i krzewów, co jest szczególnie uciążliwe dla osób z alergiami wziewnymi.

Woda ma ogromny wpływ na zdrowie psychofizyczne człowieka. Możliwość kontaktu z różnymi formami wodnym w mieście jest jednym z warunków ksztatowani wysokiej jakości przestrzeni publicznych. Dzieki wieloletnim badaniom jaukowym, które dowiody dobrecynnego wplywu wody samopoczucie człowieka', dziśs chętnie wprowadza się miejurban public spaces and have become tourist in tractions, like the fountain in Duszniki, which was
built in 1905. It was already a regional attraction at the time - one of the tallest contemporary founa height of 45 metres $^{3}$. The fountain has been restored in modern times and during summertime, lit and playing sounds, the fountain presents water,

2. Urban water forms in sustainable design The significance of urban water forms as aesthetic elements of urban spaces started to be acknowledged in the XX century. Postulates regarding the tor ies of the first half of the last century, have act les of the first half of the last century, have already appeared in the Athens Charter. Over time, mainly
thanks to working within the framework of the UN research on the quality of the environment started
II. 3. Rekreacyjne fontanny w zespole Hammarby Sjostad W Sztokholmie. Autor: E. Kusińska / Recreational fountains in the Hammarby Sjostad
complex in Stockholm. Author: E. Kusinska II. 4. Wodny plac zabaw - dzielnica Vastra Hamnen na terenach dawnego
Hamnen district in the area of aformer port in Malmö. Author: E. Kusinska
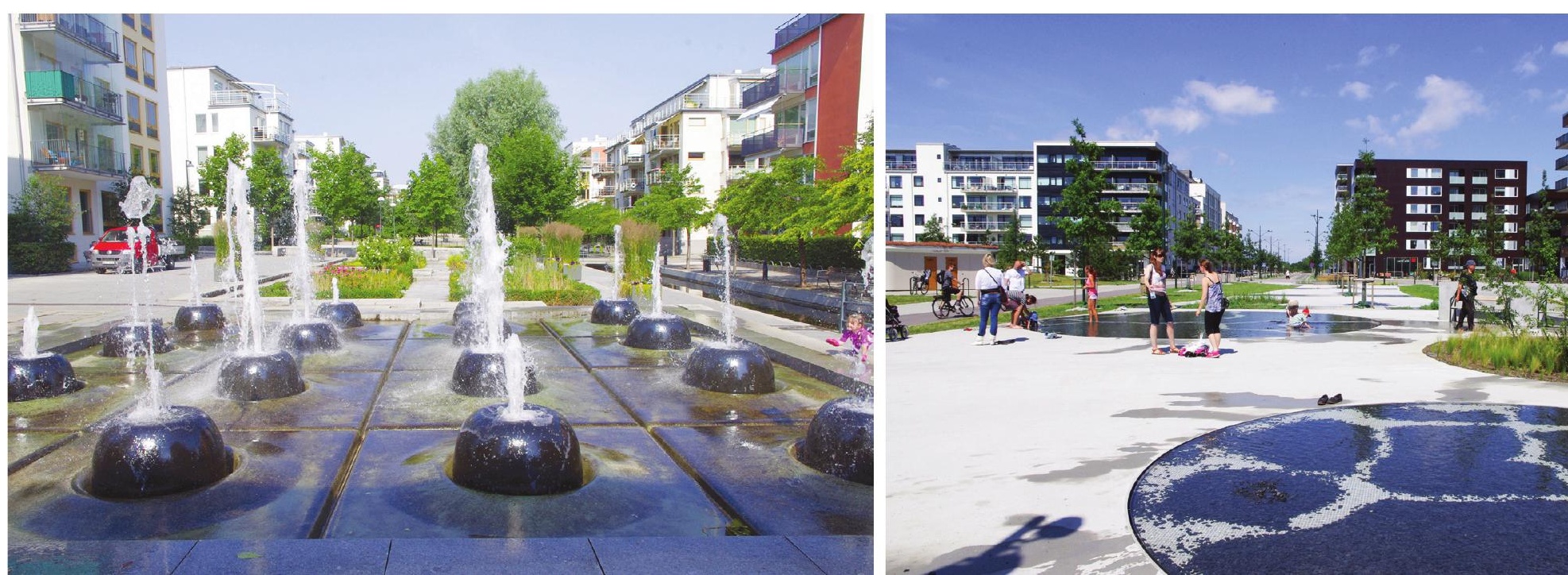


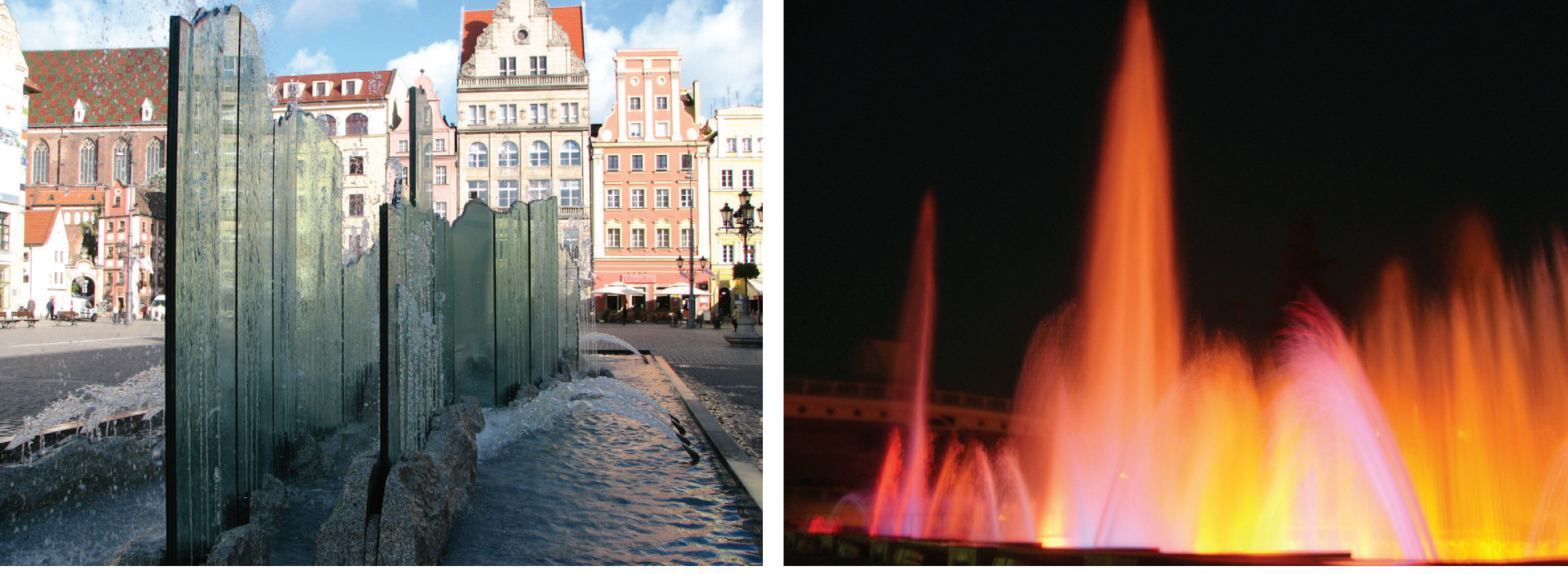

II. 5. Fontanna na wrocławskim Rynku. Autor: E. Kusińska / The fountain on Wroctaw's market square. Author: E. Kusińska

II. 6. Multimedialny pokaz - fontanny w Pradze. E. Kusińska / Multimedia spectacle - fountains in Prague. E. Kusińska

skie fontanny, kaskady itd. do przestrzeni publicznych projektowanych w sposób zrównoważony. Nowoczesne fontanny pojawiają się w najbardziej prestiżowych miejskich przestrzeniach publicznych - na głównych placach czy rynkach. Są to często miejsca, gdzie nie jest możliwe wprowadzenie dużej ilości terenów zielonych ze względu na charakter i funkcje miejsca, a także ich znaczenie historyczne. Elementy wodne często zdają się być idealnym akcentem, który doda walorów estetycznych (szczególnie woda połączona z formą przestrzenna np. rzeźbą) i przyciągnie ludzi podziwiających ruch wody i odpoczywających przy jej kojącym szumie.

Jedną z takich przestrzeni publicznych, która w silnie zurbanizowanym, historycznym wnętrzu miejskim zyskała efektowaną wspótczesną fontannę jest Plaza del Pilar - główny plac w Saragossie, pełniący funkcję historycznego rynku. Jest to dtugie wnetrze urbanistyczne, obudowane szczelnio historyczna zabudowa wtacznie z zabytkowa Bazylika de Nuestra Señora del Pilar, która jest jedna z głównych atrakcii turySeñora del Pilar, kora jest jedną z glównych atrakcji turystycznych mista. kalna for miana Na jednym z bokow placu powsta - ma ona forme kaskady opadajacej po ukón la kamiennej scianie, a następnie rozlewającej ję w formie strumienia w posadzce placu. Kazat kow obrys Ameryki Poludnowej - co w zanyle projektantow miało nawiązywac do kulturalnego dziedzictwa Hiszpanii i krajów hiszpanskojezycznych. Wyjalkowy ksztalt tego zalożenia wodnego daje niezapomniane efekty wizualne - płynącej skośnej sciany wody, która lączy się z posadzką placu i domyka historyczną kompozycję wnętrza Plaza del Pilar. Prosta forma tego założenia pomimo swojej dużej kubatury nie dominuje w przestrzeni miasta, ale dobrze komponuje się z historyczna architektura

Nowoczesne rozwiązania technologiczne umożliwiają kształtowanie fontann o calkowicie odmiennym od tradycyjnego charakterze. Są to założenia, w których zarówno forma fontanny jak i strumien wody traktowany jest "umownie" i zostaje rozbity na bardzo drobne cząsteczki i przekształcony w mgłę wodną. Ma ona wizualnie zupełnie odmienny charakter od opadajacej w tradycyjnych fontannach kaskady wodnej. Mgła wodna jest lekka i unosi się na większym obszarze, ity of contact with various water forms within a city is one $o$ the conditions of shaping high quality
public spaces. Thanks to many years of scientific studies, which have proven the beneficial imptific of water on human well-being ${ }^{6}$, fountains, cascades, etc. are eagerly being introduced into public spaces that are being sustainably designed. Modern fountains appear in the most prestigious urban public spaces - on main plazas or squares. Thes are often places where the introduction of a large amount of green areas is often impossible due to the character and function of a place, as well as
its historical significance. Water elements often apqualities (particularly water combined with a spatial form, e.g. a sculpture) and attracting people admiring the movement of water and relaxing to its soothing sound.

One of such public spaces - which has gained an urbanised historical urban interior -is Plaza del Pily the main square in Saragossa, which plays the part of a historical market square. It is a long urban interior, tightly surrounded by historical buildings, includ ing the historical Basilica de Nuestra Señora del Pilar, which is one of the main tourist attractions of the city. A unique form of a fountain called "Fuente de of the square - it has the form of a cascade that falls along a diagonal stone wall, which then spreads in the form of a stream on the surface of the square. The shape that the water cuts out in the stone wall has the outline of South America - which, according to the idea of the designers, was to be a reference to the cultural heritage of Spain and Spanish-speaking ing, diagonal wall of water which connects with the surface of the square and rounds out the historical composition of the interior of Plaza del Pilar. The simple form of this layout, despite its large volume, does not dominate in the space of the city, but fits very well into the historical architecture. Modern technological solutions make it possible to shape fountains in a manner that is completely layouts in which both the form of a fountain as pear to be the ideal accent, which adds aesthetic out provides unforgettable visual effects - a flow- zmieniając swoją formę, kolor, transparentność W zależności od warunków atmosferycznych w otoczeniu. Mgla wodna $w$ przestrzeni publicznej daje niezwykle oryginalny efekt plastyczny - jest zmienna i nieograniczona żadnym zbiornikiem wodnym, dodatkowo podświetlona może stać się ciekawym zjawiskiem plastycznym również w nocy. Tego typu fontann sprawdza sie w wielu miejskich przestrzeniach publicznych. $W$ parkach i na zielonych skwerach nawilza i nawadnia otaczające tereny zielone. Na placach i ulicach takie rozwiazanie bardzo dobrze sie sprawdza poniewaz nie potrzebna jest w tym wypadku niecka na zbierajaca sie wode. Fon jest $w$ formie mgly możn wylaczý, aby zagospoderować tym w form wy ply moźna wy zcyc, aby zagospodarowad tymwy. Mgla prodna jest szczegónie pozytyie odbirana plo wy. Mgu wrostrzen placu ina inne funkcie np. plac handlouzr sredni, ale bezpieczny kontakt z woda, poniewaz przyjemnie

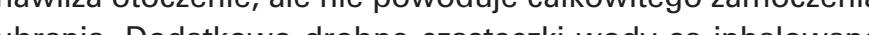
ubrania. Dodatkowo drobne cząsteczki wody są inhalowane przez czlowieka powodujac natychmiastowe nawiżenie bło sluzowych i układu oddechowego.

\section{Rewitalizacje współczesnych miejskich przestrzeni} publicznych

Przemiany społeczno-ekonomiczne II połowy XX wieku doprowadziły do zmiany kształtu i funkcjonowania wspótczesnych miast. Rewolucja informacyjna, nowoczesne technologie produkcji oraz postulaty związane z ochroną środowisk doprowadziły do przeksztaicenia struktury gospodarczej wielu krajów, a szczególnie widać to na przykładzie krajów europejskich. Postęp technologiczny i przenoszenie produkcji do innych czéści świata sprawiło, że w wielu miastach zostaty zamknięte zakłady przemysłowe, fabryki, stocznie, a także obsługujące je przedsiębiorstwa jak np. składy kontenerowe, magazyny, kopalnie itd. Dodatkowo zmiany polityczne, które przetoczyły sie przez Europe na przełomie lat 80. i 90 . ubiegłego wieku spowodowaty, że w krajach Europy Zachodnie Wschodniej zlikwidowano zie kraz i skłáw wojk Wóre istniały tam od czasów II wojny światowej. W wynik W Wh tyo obszarowo tery poprzemyow mojckowe, czescich Whary wieu osrodkow miejskch podjely azial

Władze wielu ośrodkow miejskich podjęły działania w kierunku restrukturyzacji i rewitalizacji tych opuszczonych i często zdegradowanych obszarow miasta. Duze rewitalizacyjne projekty urbanistyczne były realizowane zarówno $w$ dużych me tropoliach jak np. Londyn, Paryż, czy Hamburg, ale równiez w mniejszych ośrodkach miejskich jak Malmö czy Göteborg. Rewitalizacja dużych obszarów miasta daje szanse na stwozenie zupełnie nowej tkanki urbanistycznej - dzielnic o zdefiniowanej funkcji i kompozycji przestrzennej. Bardzo ważn było kształtowanie nowych miejskich przestrzeni zgodni z zasadami zrównoważonego projektowania - co dało szanse nie tylko na wlaczenie tych obszarow do struktury miasta, ale również na przywróceniu środowiska przyrodniczego $n$ tych terenach. Charakterystyczne dla projektów rewitalizacj well as the water stream, are treated as "imaginary" and it becomes divided into very fine particles and turned into a water mist. It has a completely differoft visual character from the falling water cascade is suspended over a larger area, changing its form, colour and transparency depending on the atmospheric conditions of the surroundings. Water mists provide an extraordinarily original effect to a public space - they are variable and not bound by any wacan night as well. This type of fountain works very well in urban public spaces. In parks or in green squares they increase humidity and irrigate the surrounding green areas. On squares and streets, such a solution also works very well because there is no need for a recessed pool to gather any water. A fountail rine form of a mist can be turned off to tempopurposes, e $g$ organise a market Water mists are particularly well received by users of public spaces - they provides them with a direct, yet safe contac with water, because the water mist pleasantly humidifies the surroundings, but does not cause the complete soaking of garments. In addition, the fine water droplets are inhaled by people, causing an and the respiratory tract.

3. Revitalisation of modern urban public spaces The socio-economic changes of the second half of the XX century led to a change in the shape and functioning of modem chlies. The information postulates associated with the protection of the environment led to the transformation of the economic structure of many countries, which is particularly visible on the example of European ones. Technological progress and the relocation of production plants to other parts of the world have led to a situation in which industrial plants, factories, ike container yards, warehouses, mines, etc, have been closed down.

In addition, the political changes that swept across Europe at the turn of the 1980's and 1990's caused many military bases and depots - which had been
there since the times of the Second World War to become closed. As a result of these changes, many umban centres gained large post chdungesia post-production and post-military areas, which were often located in very attractive parts of a city (e.g. post-port areas occupied expansive coastal areas and separated cities from water.

The authorities of many urban centres took acthe in the direction of restructuring and revitaliscities. Large revitalisation urban design projects were carried out both in large metropolises like, for instance, London, Paris or Hamburg, but also in smaller urban centres like Malmö or Göteborg. The revitalisation of large parts of a city creates an opportunity to create completely new urban tissue - districts with a defined function and urban comurban spaces in accordance with the principles of sustainable design - which created the oppor- 
jest tworzenie nowych, atrakcyjnych przestrzeni publicznych, $w$ których poszukuje się nowoczesnych rozwiązań architektoniczno - urbanistycznych oraz odniesień do tożsamości miejsca. Funkcje przestrzeni publicznych na obszarach rewitalizowanych nadążają za potrzebami ich przyszłych mieszkańców, których styl życia zmienia się w związku ze zwiększaniem sie ilości czasu wolnego, większa świadomościa prozdrowotna oraz ekologiczna?. Jedną z wiodących funkcji nowych przestrzeni publicznych jest rekreacja rozumiana w bardzo szerokim znaczeniu - projektuje sie zarómno miejsca spotkeprzestzenie dla uprawiania sportu, tereny zielone dla niezoprzewizzujace od zoczynu, ciagi komunikacyne przystoso-

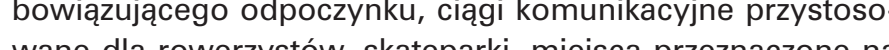

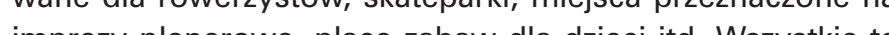
ínprezy plen fowe, place zabaw dh dziecilit. Wszystie te rożnodne funkce prekreacyne wplecione sa w przestizen cerk uksztattowaniu terenu, obiektom matej architektury czy elementom przyrody i natury, takim jak zieleń czy woda.

Założenia wodne w przestrzeniach publicznych rewitalizowanych obszarów miejskich pojawiają się często łącząc w sobie wiele funkcji. Przede wszystkim elementy wodne - zbiorniki, fontanny kaskady w przestrzeni publicznej są częścią systemu SUDS ${ }^{8}$, który w zrównoważonym projektowaniu ma za zadanie zatrzymywanie wody deszczowej w miejscu opadu a następnie umożliwienie jest wsiąkania w grunt, parowania lub powtórnego wykorzystania do celow uzytkowych. Sposoby projektowania przestrzeni publicznych z wykorzystaniem nowoczesnych fontann umożliwiają spełnienie najważniejszych atrybutów decydujących o wysokiej jakości przestrzeni publicznej takich jak: integracyjność, dostępność i ciaggłość, edukacyjność, komfort i bezpieczeństwo użytkowania, wizerunek miejsca, atrakcyjność funkcjonalna\%.

Podobne znaczenie mają formy wodne dla przestrzeni publicznych o tradycyjnych funkcjach głównego placu mieiskiego czy rynku, które również podlegają przekształceniom chociaż nie w tak catościowym charakterze jak na obszarach poprzemystowych. Wspótczesne miasta staraj sie przyciagnác do siebie jak naipej oduiedzajacych - turystyka staje sie jedn z naiminiejzych galezi gospodaki wilu krajów i os jodkow

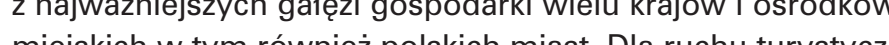
miejskich w ty mown nego back wa winy jest wizen się zabyki, obieky kulf wizello -gastrono oczne oraz atrakcyja wizualnie przestrzeń miejska. Miejskie fontanny staly się jednym z elementow ksztaltowania wizerunku miast. Historyczne fontanny, ktore dawniej miały często znaczenie użykowe dzis staja się ozdobą placów i rynkow miejskich. Natomiast nowoczesne zalożenia wodne mają szansę stać się uzupełnieniem historycznej kompozycj architektoniczno-urbanistycznej, ale z wykorzystaniem nowoczesnej formy oraz roznnorodnych technologii interaktywnych. Nowoczesne założenia wodne często powstają nie bez kontrowersji, jak np. fontanna na wrocławskim Rynku, które nowoczesna forma wywołała wiele dyskusji w środowisku architektów i konserwatorów. Fontanna zbudowana ze szklanych, pionowych tafli osadzonych w kamieniu, oblewanych wym świattem) miała być obiektem tymczasowym. Po kilku tunity to not only incorporate these areas into the structure of a city, but also to reintroduce the natuThese areas.

The creation of new, attractive public spaces in as well as references to the and urban solutions, being pursued, is characteristic of revitalisatio projects. The function of public spaces in revitalised areas are following the needs of their future residents, whose lifestyle changes due to the in creasing amount of free time and greater healthrelated and environmental awareness'. One of the ation, understood very broadly - they feature both meeting places, spaces for sports, green areas fo relaxed recreation, circulation paths adapted to cyclists, skateparks, places meant for outdoor events, playgrounds for children, etc. All of these various functions are interwoven with the public space of niture or elements of nature and the environment such as greenery or water.

Water layouts in revitalised public spaces within urban areas often appear to combine a lot of functions. Firstly, water elements - reservoirs, fountain and cascades found in urban spaces are part of the sign and is meant to retain rainwater in the de where it fell and then enables it to sink into the ground, evaporate or be reused for utilitarian purposes. Manners of designing public spaces whil using modern fountains make it possible to fulfil the most important attributes that define the high quality of public spaces, such as: integration, ac safety of use, the image of a place and function attractiveness

Water forms have a similar significance to public spaces that fulfil the traditional function of a main city square or market place and which also undergo transformations. although not in such a holistic way as in the case of post-industrial areas. Moder tourism is becoming one of the most important branches of the economy of a lot of countries and urban centres, including Polish cities. The image of a city, which is composed of historical structures, cultural facilities and museums, the hotel and gastronomy base, as well as a visually attractive urban space, is very important from the point of view of the elements of shaping the image of cities.

Historical fountains which had utilitarian signifcance in the past now decorate city squares and markets. Meanwhile, modern water layouts have the chance to become a supplementation of historical architectural and urban compositions, bu tive technologies. Modern water layouts are ofte built not without controversy, like in the case of the fountain on Wroclaw's market square, the modern form of which caused much discussion in architectural and conservation circles. The fountain, buil out of vertical glass sheets fastened to a stone suface, which are being doused with water (in addmeant to be a temporary structure. After a couple of years it has become one of the most distinct ele- latach stała się jednym z najbardziej charakterystycznych ele-

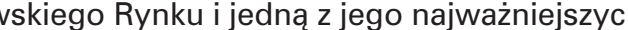
atrakcji turystycznych.

Wiele miast, w tym również w Polsce zainwestowało a multimedialne fontanny ze spektaklami typu "światło i dźwięk", które staja się miejskimi atrakcjami w sezonie letnim. Takie fontanny znajdują się w Rzeszowie, Warszawie czy Wrocławiu, a ich cykliczne pokazy na stałe wpisały sie w harmonogram letnich wydarzeń w misćcie. Tegoroczna inauguracja nowego sezonu w Multimedialnym Parku Fontann w Waszawie, która odby sie na poczatku maja przyciagne Warszawidzów. Zaprezento na poczaku maja prayciagne tlumy widzow. Zaprezentowany zosta mulimediany spektakl Ba-

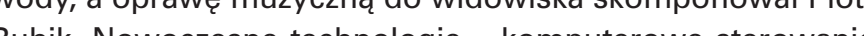
Rubik Nowoczesne techno - komputerowe sterowanie strumichia serowych projektorow wyswietlane są obrazy zgrane z oprawą muzyczną sprawiają, że tradycyjna przestrzen publiczn ztałca się w miejsce rekreacji i multimedia nej rozrywki.

\section{Podsumowanie}

Zaprezentowane w tekście przykłady realizacji fontann, kaskad, oczek wodnych itd. w przestrzeni publicznej współczesnych miast są tylko niewielkim fragmentem różnorodnych moźliwości plastycznego wykorzystania wody. W tradycyjnych fontannach, które powstawały w czasac historycznch wykorzystywano takie wlasciwosci wody jak dżwięk, ruch, możliwośc rozpraszania światta i odbijania kolorów otoczenia. Współczesne fontanny i niewielkie zbiorniki wodne zyskały wiele dodatkowych funkcji - sprzyjaja rekreacji, lagodza negatywne skutki klimatyczne urbanizacji, zachowują bioróżnorodność, gromadzą wodę opadową itd. Nowoczesne technologie komputerowe, które przekształcają fontanny w multimedialne widowiska sprawiły, że miejskie przestrzenie publiczne zyskały dodatkowe walory estetyczne. Dziś można stwierdzić, że te założenia wodne staja sie uniwersalnym elementem upiększającym przestrzeń miejską, a dzięki postępowi technologicznemu można spodziewać się, że w przyszłości walory estetyczne wody zostana jeszcze wzbogacone.

PRZYPISY

G. Nyka, Architektura i woda - przekraczanie granic, Wydawnictwo Politechnik

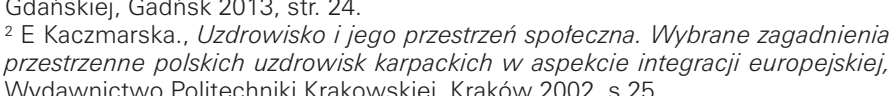
3 http://duszriki.p///atrakcje-i-turystyka-2/ciekawe-miejsca/kolorowa-fontanna/

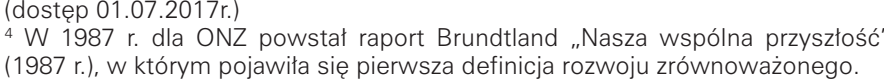

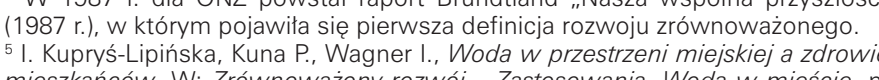
5/2014, Fundacja Sendzimira, Kraḱow 2014, s. 49-5

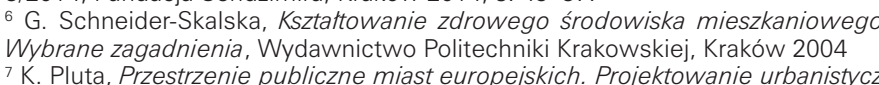
e, Oficyna Wydawnicza Politechniki Warszawskiej, Warszawa 2012, s. 57.

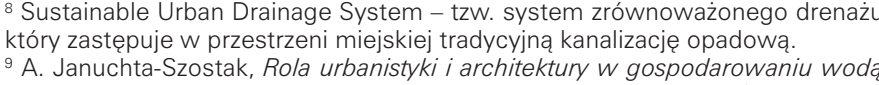
A. Januchta-Szostak, Rola urbanistyki iarchitekturtr $w$ gossopodarowaniu woda, ments of Wroclaw's market square and one of its most important tourist attractions.

Many cities, including Polish ones, have invested in multimedia fountains with "light and sound" tions during the summer season. Such fountain are located in Rzeszów, Warsaw or Wrocław, an their cyclical shows have permanently become inscribed into the schedule of summer events in their city. This year's new season inauguration in he Malch The of viewers. It featured the "Bazyliszek" multime dia spectacle, with moving images projected onto cascades of water, while the musical score of the event had been composed by Piotr Rubik. Modern technologies - the computer-based control of water streams and water curtains, on which images were projected using laser projectors, in sync with with a fountain transform into a place of recreation and multimedia entertainment.

4. Conclusion

Examples of fountains, cascades, ponds, etc. in the public spaces of modern cities that were prewide array of possibilities of the visual use of the ter. In traditional fountains, which were built in hisorical times, properties of water like sound movement, the ability to disperse light and reflect the colours of the surroundings were used. Modern fountains and small water reservoirs have gained many addilional functions - they aid in recreation in terms of climate, preserve biodiversity, gathe rainwater, etc. Modern digital technologies which convert fountains into multimedia spectacles have caused urban public spaces to gain additional aesthetic value. Today we can conclude that these water layouts are becoming a universal element tha beautifies urban spaces, and thanks to technologiof water to be enriched even more in the future.

\section{ENDNOTES}

Nyka L., Architektura i woda- przekraczanie granic, Wy-
dawnictwo o olitechniki Gdańskiej, Gadńsk 2013, p. 24 . Kaczmarska E., Uzdrowisko i jego przestrzeń spotecznna
Wybrane zagadnienia przestrzenne polskich uzdrowisk kar-
packich wh assekcie integracii packich w waspekcie integracije europejskiej, Wydawnictwo
Politechniki Krakowskiej, Krakow 2002 , p.25. kolorowa-fontannia/ (retrieveded on 01.07 .2017 . 2017)
4 In 1987 the Brundtand commission prepared the "Our (1987) report for the UN. It contained the Kuprýs-Lipińska l.., Kuna P., Wagner l., Woda w w prestrzzeni
miejskiej a zdrowe mieszkańcow, W: Zrónnowazony rozWoj-Zastosowania. Woda w mieście, iss. 5/2014,
Sendzimira, Krakow 2014, p. 49-57.
6 Schneider-skalska a. Kstattonanie zdrowego środowisk miestidaniowego. Wh. Krane zagandanienia, Wydawnictwo Po-
litechniki Krakowskiej, Krakow 2004

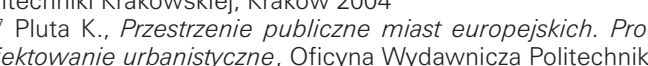
Warszawskiej, Warsaw 2012, p. 57.
s Sustainable Urban Drainage System - it replaces traditional rainwater drainage systems.
9 Januchta-Szostak A., Rola urbanistyki i architektury $w$ go-
spodarowaniu woda. W: Zrównoważony rozwói - Zastoso spodarowaniu woda, W: Zrównowazony rozwój- Zastoso-
wania. Woda w miescie, iss. 5/2014, Fundacja Sendzimira,
Krakow 2014, p.32-44. 


\section{LITERATURA}

[1] Januchta-Szostak A., Rola urbanistyki i architektury w gospodarowaniu woda, W: Zrównoważony rozwój-Zastosowania. Woda w mieście, nr 5/2014, Fundacja Sendzimira, Kraków 2014.

[2] Kaczmarska E., Uzdrowisko i jego przestrzeń społeczna. Wybrane zagadnienia przestrzenne polskich uzdrowisk karpackich w aspekcie integracji europejskiej, Wydawnictwo Politechniki Krakowskiej, Kraków 2002.

[3] Kupryś-Lipińska I., Kuna P., Wagner I., Woda w przestrzeni miejskiej a zdrowie mieszkańców, W: Zrównoważony rozwój - Zastosowania. Woda w mieście, nr 5/2014, Fundacja Sendzimira, Kraków 2014

[4] Nyka L., Architektura i woda - przekraczanie granic, Wydawnictwo Politechniki Gdańskiej, Gadńsk 2013.

[5] Pawlak D., Estetyczne i użytkowe walory fontann, W: Społeczne i krajobrazowe walory wody w środowisku miejskim, praca zbiorowa pod redakcją A. Januchty-Szostak, Wydawnictwo Politechniki Poznańskiej, Poznan 2011, s. 187-192.

[6] Pluta K., Przestrzenie publiczne miast europejskich. Projektowanie urbanistyczne, Oficyna Wydawnicza Politechniki Warszawskiej, Warszawa 2012

[7] Schneider-Skalska G. Kształtowanie zdrowego środowiska mieszkaniowego. Wybrane zagadnienia, Wydawnictwo Politechniki Krakowskiej, Kraków 2004.

\section{BIBLIOGRAPHY}

[1] Januchta-Szostak A., Rola urbanistyki i architektury w gospodarowaniu wodą, W: Zrównoważony rozwój - Zastosowania. Woda w mieście, iss. 5/2014, Fundacja Sendzimira, Krakow 2014.

[2] Kaczmarska E., Uzdrowisko i jego przestrzeń społeczna. Wybrane zagadnienia przestrzenne polskich uzdrowisk karpackich w aspekcie integracji europejskiej, Wydawnictwo Politechniki Krakowskiej, Krakow 2002

[3] Kupryś-Lipińska I., Kuna P., Wagner I., Woda w przestrzeni miejskiej a zdrowie mieszkańców, W: Zrównoważony rozwój - Zastosowania. Woda w mieście, nr 5/2014, Fundacja Sendzimira, Krakow 2014.

[4] Nyka L., Architektura i woda - przekraczanie granic, Wydawnictwo Politechniki Gdańskiej, Gdańsk 2013.

[5] Pawlak D., Estetyczne i użytkowe walory fontann, W: Społeczne i krajobrazowe walory wody w środowisku miejskim, praca zbiorowa pod redakcją A. Januchty-Szostak, Wydawnictwo Politechniki Poznańskiej, Poznań 2011, p. 187-192.

[6] Pluta K., Przestrzenie publiczne miast europejskich. Projektowanie urbanistyczne, Oficyna Wydawnicza Politechniki Warszawskiej, Warsaw 2012

[7] Schneider-Skalska G. Kształtowanie zdrowego środowiska mieszkaniowego. Wybrane zagadnienia, Wydawnictwo Politechniki Krakowskiej, Krakow 2004. 